\title{
BASS-MODELING FOR FAST FASHION LADY'S SHOES BASED ON CONSUMER BEHAVIOR
}

\author{
Keyu HOU ${ }^{1}$, Jinzhi HE ${ }^{1}$, Lisha LIANG ${ }^{1}$, Jingjing $\mathrm{LI}^{1}$, Jin $\mathrm{ZHOU}^{1,2^{*}}$ \\ ${ }^{1}$ Sichuan University, College of Light Industry, Textile and Food Engineering, National Engineering Laboratory for Clean \\ Technology of Leather Manufacture, Section of Chengdu No. 24 Southern Yihuan, 610065, Chengdu, China, \\ 625368881@qq.com
}

${ }^{2}$ Science Lab, Zhejiang Red Dragonfly Footwear Co., LTD., Zhejiang Province, Wenzhou, 325100, Wenzhou, China, zj_scu@scu.edu.cn

Received: 18.03.2019

Accepted: 19.09.2019

https://doi.org/10.24264/Ifj.19.3.1

\section{BASS-MODELING FOR FAST FASHION LADY'S SHOES BASED ON CONSUMER BEHAVIOR}

ABSTRACT. Fast fashion is prevalent in the retail industry, however, plotting its life cycle becomes problematic as that feedback from sales record is even considered to be late for them. So, variables in the process of consumer behavior are potential ones for life cycle assessment of fast fashion products. Currently, most studies of Bass model chose the sales data, but whether the Bass model can also be applied for those in consuming process has not been evaluated; meanwhile, if the modeling based on consumer behaviors such as attention and fitting are available, we can project forward in time and make predictions much earlier than those based only on sales. Therefore, we developed a special system and it was used to collect the attention and fitting records. Our results show that only moderate Bass-fitting results were found for individual-level data; while, good to excellent results could be obtained for the accumulated data. Further, a moderate to good correlation was found between the sales and attention on one hand, and sale and fitting on the other. Regression models including Bass Model equations could be applied to predict the sales by either the attention or the fitting data. Overall, variables of consumer behavior, such as attention and fitting, were found to be suitable for Bass Modeling; further they were found to be good indicators to predict sales. These efforts advanced the time required to predict the sales trend of fast fashion sandals and make the predictive protocols more reliable.

KEY WORDS: LCA, RFID, attention-fitting-buying model, attention and fitting, off-line retailing

\section{MODELUL BASS APLICAT ÎN CAZUL PANTOFILOR DE DAMĂ ÎN REGIM DE MODĂ RAPIDĂ PE BAZA COMPORTAMENTULUI} CONSUMATORILOR

REZUMAT. Moda rapidă este predominantă în industria de vânzare cu amănuntul, însă, trasarea ciclului său de viață devine problematică, întrucât feedback-ul provenit din înregistrările de vânzări este considerat întârziat în acest caz. Așadar, variabilele în comportamentul consumatorului sunt variabilele potențiale pentru evaluarea ciclului de viață al produselor de modă rapidă. În prezent, majoritatea studiilor care utilizează modelul Bass au selectat datele din vânzări, dar nu s-a analizat dacă modelul Bass poate fi aplicat și în cazul procesului de consum; în același timp, dacă modelele bazate pe comportamentele consumatorilor sunt disponibile, cum ar fi atenția și potrivirea, putem proiecta în timp și face predicții mult mai timpuriu decât doar pe baza vânzărilor. Prin urmare, s-a dezvoltat un sistem special și a fost utilizat pentru colectarea înregistrărilor privind atenția și potrivirea. Rezultatele noastre arată că s-au găsit doar constatări moderate utilizând modelul Bass pentru datele la nivel individual, în timp ce rezultate bune și excelente s-au obținut pentru datele acumulate. Mai mult, s-a găsit o corelație moderată până la bună între vânzări și atenție pe de o parte, și între vânzare și potrivire pe de altă parte. Modelele de regresie, inclusiv ecuațiile modelului Bass, ar putea fi aplicate pentru a prezice vânzările fie prin intermediul datelor legate de atenție, fie de potrivire. În general, variabile ale comportamentului consumatorului, cum ar fi atenția și potrivirea, s-au dovedit a fi adecvate pentru modelul Bass; în plus, s-a dovedit că sunt indicatori buni pentru a prezice vânzările. Aceste eforturi au scurtat timpul necesar pentru a prezice tendința de vânzare a sandalelor de modă rapidă și au făcut protocoalele predictive mai fiabile.

CUVINTE CHEIE: LCA, RFID, model atenție-potrivire-cumpărare, atenție și potrivire, vânzare cu amănuntul off-line

MODÈLE DE DIFFUSION DE BASS POUR CHAUSSURES FEMME À LA MODE RAPIDE BASÉ SUR LE COMPORTEMENT DU CONSOMMATEUR RÉSUMÉ. La mode rapide prévaut dans le secteur de la vente au détail. Toutefois, il est difficile de tracer son cycle de vie, car le retour d'information concernant les ventes est considéré tardif. Ainsi, les variables dans le processus de comportement du consommateur sont des variables potentielles pour l'évaluation du cycle de vie des produits de la mode rapide. Actuellement, la majorité des études qui en utilisent le modèle Bass ont choisi les données de vente, mais on n’a pas encore évalué si le modèle Bass pouvait également être appliqué pour le processus de consommation; dans le même temps, si la modélisation basée sur les comportements des consommateurs est disponible, tels que l'attention et l'ajustement, nous pouvons nous projeter dans le temps et faire des prévisions beaucoup plus tôt que juste en fonction des ventes. Par conséquent, nous avons développé un système spécial qui a été utilisé pour collecter les enregistrements d'attention et d'ajustement. Nos résultats montrent qu'on a trouvé seulement des résultats modérés en utilisant le modèle Bass pour les données au niveau individuel; tandis que des résultats bons à excellents ont été obtenus pour les données accumulées. De plus, une corrélation modérée à bonne a été trouvée entre les ventes et l'attention d'une part, et entre la vente et l'ajustement de l'autre. Des modèles de régression comprenant des équations du modèle Bass pourraient être appliqués pour prédire les ventes en fonction des données d'attention ou d'ajustement. Dans l'ensemble, les variables du comportement du consommateur, telles que l'attention et l'ajustement, ont été jugées appropriées pour le modèle Bass; en outre, ils se sont révélés être de bons indicateurs pour prédire les ventes. Ces efforts ont permis de gagner du temps pour prédire la tendance des ventes de sandales à la mode rapide et rendre les protocoles prédictifs plus fiables. MOTS CLÉS : ACV, RFID, modèle attention-ajustement-achat, attention et ajustement, vente au détail hors ligne

\footnotetext{
* Correspondence to: Jin ZHOU, Science Lab, Zhejiang Red Dragonfly Footwear Co., LTD., Zhejiang Province, Wenzhou, 325100, Wenzhou, China, zj_scu@scu.edu.cn
} 


\section{INTRODUCTION}

Success in the fashion apparel industry by brands such as ZARA [1], GAP [2] and UNIQLO [3] has deeply changed world fashion patterns. All of those companies created a new business model which was called "Fast fashion". Fast-fashion is featured as highly fashionable product design and short production and distribution times [4]; meanwhile, a shorter life time of either usage or prevalence [5] is also one of its features. The key principle of fast fashion is the 'fast', not only in the design and distribution process, but also in the marketing. Usually, information from the market feedback is mainly from the sales record, questionnaire from costumers or investigation from specialists. However, with exception of the sales data, the above two approaches are subjective; although the sales are considered as the objective data which has been widely used in the nowadays products' evaluation, it represents the final choice after several key events in the consuming behavior, such as researching, attention and fitting activities and it means that the time to obtain the sales record is later than that of attention and fitting.

In this study, three areas of theoretical foundation are considered: Fast Fashion Theory, Life cycle assessment and modeling technologies, and Consumer Behavior Theory.

In the theory of Bass model, two indicators are available: one is "innovators", another is "imitators" [6]. Innovators usually indicate that consumers seldom involve repeat purchases, because new generations will quickly replace previous ones; while "imitators" imply that the followers will repeat purchase products which are bought by pioneer groups. In terms of this classification, fast fashion belongs to innovatorstyle, thereby, it is not only emphasizing the enhanced design, but also the quick response either in the producing or in the marketing period. The relationship between the enhanced design and quick response was discussed by Cachon et al. [7], who established a series of mathematical models for evaluating the value of the traditional, quick response, enhanced design and fast fashion systems. Their findings proved that fast fashion can be defined as a combination of the quick response and enhanced design; each of this pair of systems is complementary rather than mutually exclusive. Other literature studies were mainly focused on market strategies for fast-fashion management [3, 8-9].

There are several ways to define the life cycle of a product [10]: some refer to the process from the conceptual design to the manufacturing process and then to the product entering and exiting the market [11]; while others merely focus on the sales section, calculating from the first promotion in the market to its exit [12]. Fortunately, nowadays such process can be quantified by Life Cycle Assessment (LCA) protocols [13-15]. A large number of products have been assessed in terms of life cycle [16]. Protocols for LCA can be achieved in the following ways: an analogy method [17], sales growth rate [18], a penetration method [19] and mathematical modeling [20]. Further, several types of algorithms were proposed to fit the curves of sales [21, 22]. For instance, the Comperz Model [8] was used to predict daily consumption of products; while those with a shorter life cycle might be assessed by the Bass or Modified Bass Model [6, 23, 24]. Thereby, according to the LCA, retailers can master the rhythms of the product and make as much profit as possible.

A consumer's behavior involves the strategy developed and actions used before making the purchase decision [25]. Both psychology and physiology are involved in the consumption process. Psychological aspects involve price comparison, decision making and anticipation of buying; whereas, physiology [26] involves the physical actions and movement of consumers. Theoretically, a consumer's behavior is a direct response to a product, which can be depicted as: attention-fitting-buying 
process. A consumer first learns about products from his or her interests [27, 28]; then utilizes their knowledge and life experience to further comprehend them; afterwards, they make a judgment and establish an attitude regarding the product. This process can be quantified in terms of attention paid by the consumer, fitting, and the final buying decision.

Effective attention plus good fitting experiences would contribute toward the final action of purchase. Thereby, adding the attention-fitting-buying into modeling process of fast-fashion products makes the recognizing and plotting of life cycle for them much earlier and it would timely assist managerial strategy making, such as deciding the time to design a new generation to replace an older or declining one. Unfortunately, current literature did not include any studies focusing on the consumer behavior process such as attention or fitting. Research questions were asked: if we obtain the attention and fitting information and build the quantified model with the help of the factors of attention and fitting, we can project forward in time and make predictions much earlier than those based only on sales. Further, if the regression formula between the attention and sale or the fitting and sale are to be obtained, sales could be predicted by the attention or fitting records, which are earlier than those of sales.

Hence, in this study, we first aim to achieve data collection from the consumer behavior process by a special developed system which is installed at the offline-stores and is used for recording attention and fitting data. Then we are to develop Bass Models with those consumer behavior factors, where attention-fittingbuying model is proposed. Further, correlations between attention-sales and fitting-sales are to be explored and regression formulas involving the Bass Model are to be established. Finally, a sensitive method to evaluate fast fashion shoe products is to be built. Hypothesis was proposed here (1): Consuming behaviors such as attention and fitting are available in the Bass modeling process; (2): Sales of fast-fashion sandals could be predicted by Bass models based on either the attention or the fitting record.

\section{METHODS}

In this study, ladies' sandals were set as our research target, since this style of footwear is fashion sensitive and commonly used in a relatively short and specific period - summer. Both the consumers' behavior of attention to a product and their fitting activities, as well as the sales in 77 offline stores installed with data acquisition systems were obtained. These shops were a famous Chinese footwear brand which has more than 4000 offline retailers over the Chinese mainland and whose annual footwear sales revenue was more than 3 billion Yuan (0.6 billion USD). The data acquisition period was set between May and December 2017 (7 months), and this period was the whole sales cycle for ladies' sandals.

Three kinds of parameters of consumer behavior were defined in this study: focusing attention on the product and fitting activities (consumer behavior), sales records (the result of consumer behaviors). Consumer behavior was recorded by the RFID systems, which were composed of a recorder and a label. The recorder was located underneath the showing pad and fitting areas, where the shoes were labeled by their RFID card. If the recorder noted that the labeled shoe was removed (that is, the consumer paid attention to the product then picked up the shoe to examine it closely) for at least 10 seconds, it would be considered a successful attention record. Similarly, when the consumer wore the labeled shoe in the fitting area for more than 10 seconds, the recorder in the fitting zone would consider this action as a successful fitting. The sales records were exported from the company's sales software system. The whole data acquisition period was done in accordance with the business opening time of the retailers (10:00-21:00). 
Accumulated Attention (AA) can be calculated by the sum of each attention record (AT) in a k period, and its mathematical formula is shown as:

$$
-1-t_{s}=\sum_{i=1}^{k}-4 T_{i}
$$

where, the $i$ is one day within the collecting period, $i=1,2,3 \ldots, l, k ; k$ is the whole product data collection time; ATi is the individual attention paid by a consumer to a product in an exact time;

Similarly, Accumulated Fitting (AF) can be calculated by the sum of each fitting record (FT) in a $\mathrm{k}$ period, and its mathematical formula is shown as:

$$
A F_{k}=\sum_{i=1}^{k} F T_{i}
$$

where, the $i$ is one day within the collecting period, $\mathrm{i}=1,2,3 \ldots, \mathrm{l}, \mathrm{k}$; $\mathrm{k}$ is the whole product data collection time; $\mathrm{FTi}$ is the individual fitting made by a consumer to a product in an exact time;

Accumulated Sales (AS) can be calculated by the sum of each sale record (SA) in a k period, and its mathematical formula is shown as:

$$
A S=\sum_{i=1}^{k} S A_{i}
$$

where, the $i$ is one day within the collecting period, $\mathrm{i}=1,2,3 \ldots, \mathrm{l}, \mathrm{k} ; \mathrm{k}$ is the whole product data collection time; SAi is the individual sale at an exact time;

Attention, fitting, and sales data were used in the Bass Modeling and the mathematical formulas of the Bass Model are shown below:

$$
\begin{aligned}
& n_{(t)}=m \frac{p(p+q)^{2} e^{-(p+q) t}}{\left[p+q e^{-(p+q) t}\right]^{2}} \\
& \mathrm{~N}_{(t)}=m \frac{1-e^{-(p+q) t}}{1+\frac{p}{q} e^{-(p+q) t}}
\end{aligned}
$$

where, $\mathrm{n}(\mathrm{t})$ is the predicted individual attention/ fitting/sales and $\mathrm{N}(\mathrm{t})$ is the predicted aggregated attention/fitting/sales; t determines the time; the parameters of $m, p$, and $q$ indicate the potential buyers, innovative factor and simulative factors individually; $p>0, q>0$.

First of all, AT, AF and AS were computed according to Eq. 1-3; then, this data was explored in order to eliminate singular values (statistical outliers) or abnormal records; afterwards, parameters of attention, fitting and sale were set by the Bass Model. Amplitude (maximum values minus minimum values), peak value and time to peak value were used to quantify each fitting curve of the Bass Model.

One sample K-S model was first used to explore the normal distribution of the data and all the data was found to be in normal distribution; then, relationships between $A A$ and $A S$ and $A F$ and $A S$ were made according to a nonlinear regression model; accordingly, the Bass Model was involved in the regression model. All statistical models were operated under the SPSS, with a significance level of 0.05 and a confidence interval of $95 \%$.

\section{RESULTS}

Fitted Bass Models are shown in Table 1 and Figure 1. These indicate that all individual variables had moderate reliability (all $\mathrm{R}^{2}$ lower than 0.5). The maximum daily attention for fashion sandals was 175 times, and it took 52 days to become popular - a state which lasted for 8 days - and that the amplitude was 124 times. In terms of individual fitting, the daily maximum fitting was 75 , which required 49 days to reach the peak that was maintained for 13 days; while the amplitude was 53 times. For sales, in the whole period, the maximum sales per day was 6 pairs, which lasted 56 days; but this peak occurred much earlier than that of either attention or fitting and took 19 days to be reached. 
Table 1: Bass Models for Individual-level Variables

\begin{tabular}{|c|c|c|c|c|c|}
\hline Variables & $\mathrm{m}$ & $p$ & q & $\begin{array}{r}\text { Typical BASS model } \\
\mathrm{n}_{(i)}=m \frac{p(p+q)^{2} e^{-\left(p+p_{y}\right) t}}{\left[p+q e^{-\left(p+p_{y}\right) / t}\right]^{2}}\end{array}$ & $R^{2}$ \\
\hline Attention & 23323.5 & 0.005 & 0.02 & $\mathrm{n}_{(t)}=\frac{0.07 e^{-0.025 t}}{\left[0.005+0.02 e^{-0.025 t}\right]^{2}}$ & 0.400 \\
\hline Fitting & 10257.4 & 0.005 & 0.02 & $\mathrm{n}_{(t)}=\frac{0.03 e^{-0.025 t}}{\left[0.005+0.02 e^{-0.025 t}\right]^{2}}$ & 0.482 \\
\hline Sales & 7696.5 & 0.006 & 0.02 & $\mathrm{n}_{(t)}=\frac{0.003 e^{-0.026 t}}{\left[0.006+0.02 e^{-0.026 t}\right]^{2}}$ & 0.466 \\
\hline
\end{tabular}
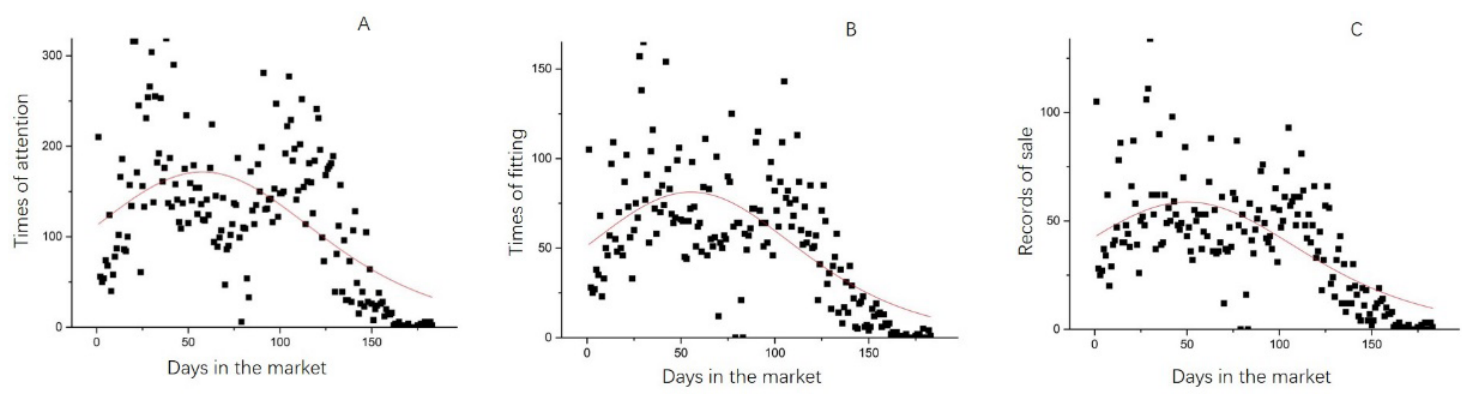

Figure 1. Bass Model for Individual Sales (C), Attention (A) and Fitting variables (B)

The aggregated Bass Models in the Table 2 indicate that all those accumulated variables had excellent fitting reliability (all $\mathrm{R}^{2}$ higher than 0.9). The accumulated curve shows (Figure 2) that the maximum attention for fashion sandals was 21816 times on the $154^{\text {th }}$ day, after which the increase ratio was less than $0.5 \%$; we defined this point as the turning point. Similar findings were obtained for accumulated fitting, where in the $153^{\text {rd }}$ day, its growth rate was less than $0.5 \%$ and the relative maximum fitting times were 9357. In terms of accumulated sales, the $143^{\text {rd }}$ day was the turning point and the maximum value was 7105 pairs.

Table 2: Bass Models for the Accumulated Variables

\begin{tabular}{ccccccc}
\hline Variables & $\mathrm{m}_{1}$ & $\mathrm{p}_{1}$ & $\mathrm{q}_{1}$ & $\mathrm{~N}_{(t)}=m_{1} \frac{1-e^{-\left(p_{1}+q_{1}\right) t}}{1+\frac{p_{1}}{q_{1}} e^{-\left(p_{1}+q_{1}\right) t}}$ & $\mathrm{R}^{2}$ \\
\hline AA & 24187.3 & 0.005 & 0.02 & $\mathrm{~N}_{(t)}=24187.3 \frac{1-e^{-0.025 t}}{1+4 e^{-0.025 t}}$ & 0.993 \\
AF & 10400.1 & 0.005 & 0.02 & $\mathrm{~N}_{(t)}=10400.1 \frac{1-e^{-0.025 t}}{1+4 e^{-0.025 t}}$ & 0.996 \\
AS & & & & & \\
& 7865.7 & 0.006 & 0.02 & $\mathrm{~N}_{(t)}=7865.7 \frac{1-e^{-0.026 t}}{1+3.3 e^{-0.026 t}}$ & 0.996 \\
& & & & &
\end{tabular}



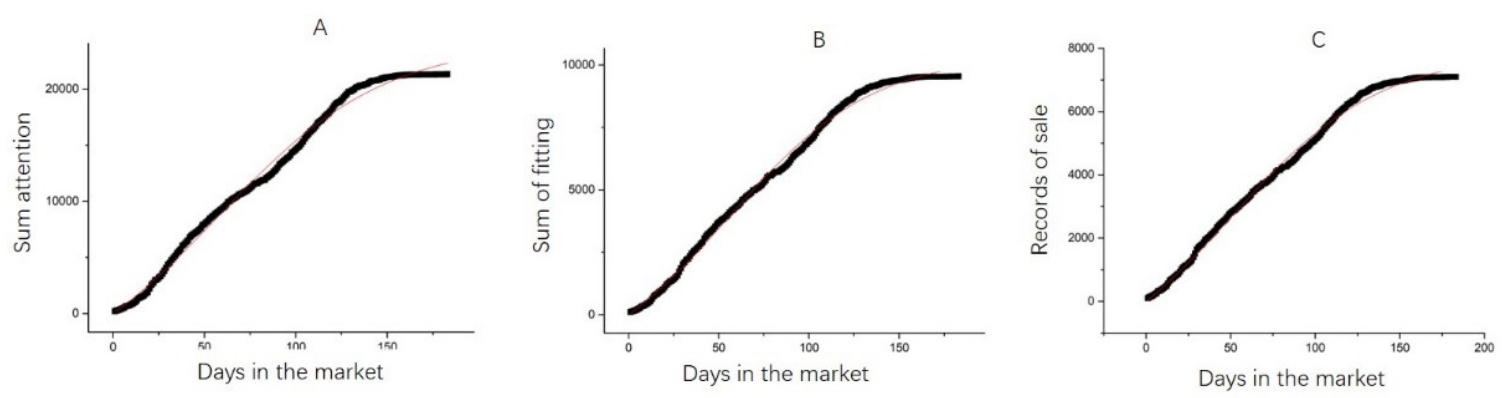

Figure 2. Bass Model for Accumulated Sales (C), Attention (A) and Fitting (C) variables

Non-linear correlations between individual sales and attention, and sales and fitting were found and a moderate to high $\mathrm{R}^{2}$ was obtained for them (Table 3 and Figure 3); while a much higher $\mathrm{R}^{2}$ was obtained for the accumulated variables (Table 4 and Figure 4). These correlations could be understood in terms of accumulated sales if 2000 attentions and 1000 fittings were made by the consumers, we could postulate that 4760 pairs of fashion sandals would be bought. In another case for accumulative sales, if 1 million attentions and 1 million fittings were made by the consumers, we could postulate that 0.472 million pairs of sandals would be bought in total. Therefore, according to the above correlations, sales could be predicted by either the attention or the fitting data.

Table 3: Correlation between the Individual Sales-Attention and Sales-Fitting

\begin{tabular}{cccccc}
\hline Correlation & Intercept & $\mathrm{B}_{1}$ & $\mathrm{~B}_{2}$ & $\begin{array}{c}\text { Fitting model } \\
\mathrm{y}=\text { Intercept }+B_{1} x+B_{2} x^{2}\end{array}$ & $\mathrm{R}^{2}$ \\
\hline Individual Sales -Attention & 0.8 & 0.4 & -0.0004 & $\mathrm{y}=0.8+0.4 x-0.0004 x^{2}$ & 0.784 \\
Individual Sales -Fitting & 1.2 & 0.7 & -0.0002 & $\mathrm{y}=1.2+0.7 x-0.0002 x^{2}$ & 0.957 \\
\hline
\end{tabular}

A

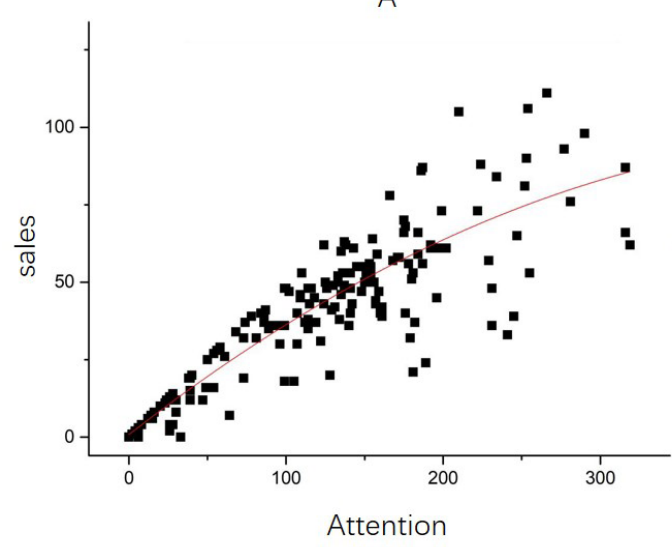

B

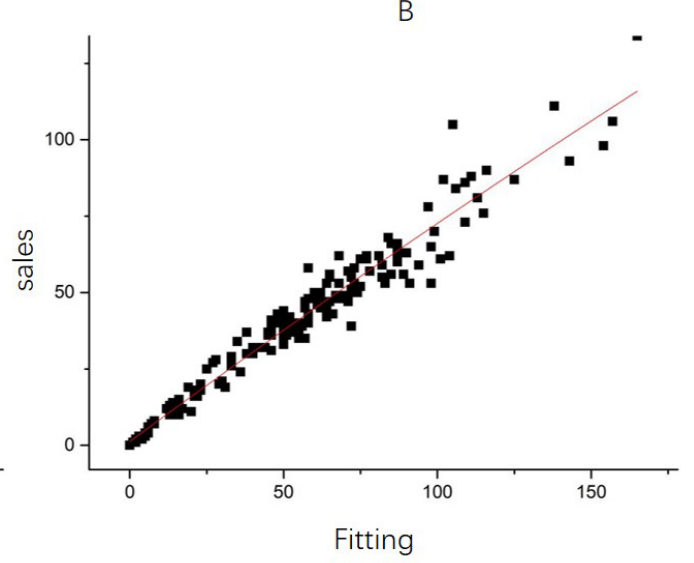

Figure 3. Non-Linear Correlation between Individual Sales and Attention (A) and Fitting (B) Variables 
Table 4: Correlation between Accumulated Sales and Attention and Fitting

\begin{tabular}{ccccccc}
\hline Correlation & Intercept & $\mathrm{B}_{1}$ & $\mathrm{~B}_{2}$ & $\mathrm{y}=$ Intercept $+B_{1} x+B_{2} x^{2}$ & $\mathrm{R}^{2}$ \\
\hline Accumulated Sales and Attention & 61.1 & 0.4 & 0 & $\mathrm{y}=61.1+0.4 x$ & 0.999 \\
Accumulated Sales and Fitting & 125.9 & 0.7 & 0 & $\mathrm{y}=125.9+0.7 x$ & 0.999 \\
\hline
\end{tabular}
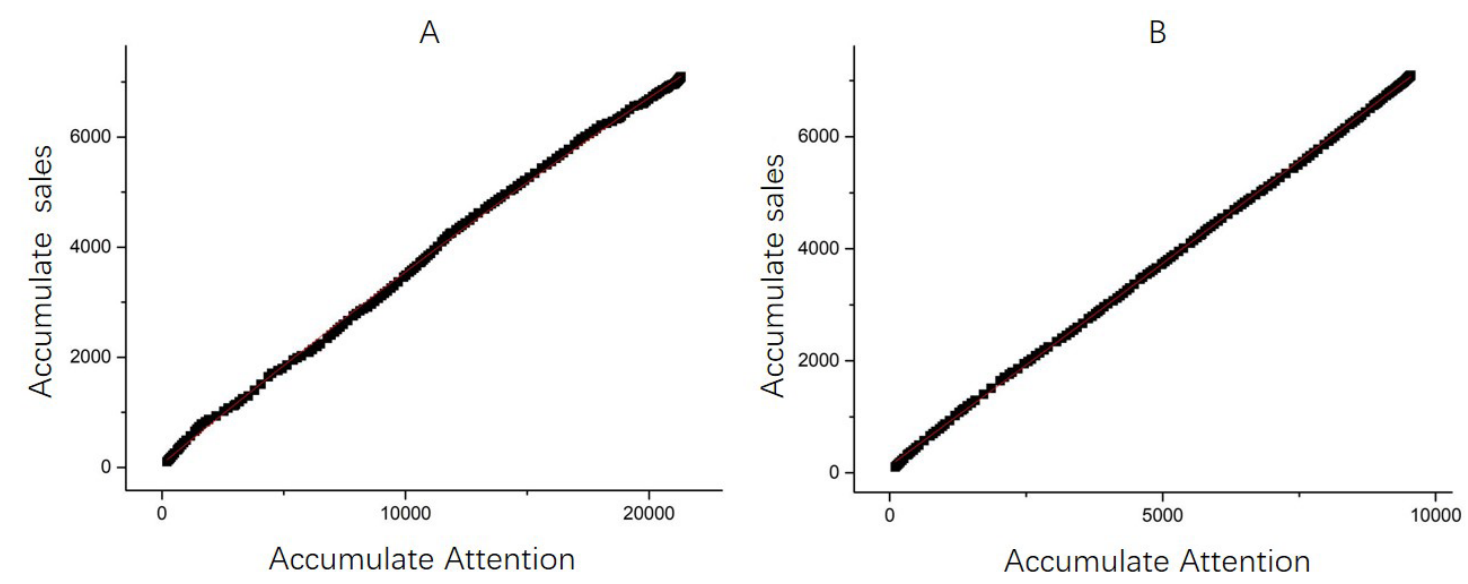

Figure 4. Linear Correlation between Accumulative Sales and Attention (A) and Fitting (B)

Variables

\section{DISCUSSIONS}

Similar to our study, LCA protocols can be applied to the internet. On the internet, by monitoring the IP addresses, online consumer behavior can be monitored on aggregate [29]; moreover, with the help of artificial intelligence (Al) algorithms that seek to comprehend human characteristics, determining the habits of consumer behavior and recommending products has a realistic basis (Tedesco). However, the fundamental infrastructure is that of big data, and critical technologies are those of data acquisition for analyzing consumer behavior. In this study, we first developed a RFID system to achieve such data; then, based on this data, we further studied consumer behavior. According to our results, the protocol used to collect the attention and fitting data was found to be reliable and could be applied in other fastfashion product research.

Guo [24] used aggregate market data in Bass Modeling to provide a distinct, dynamic, and local perspective on consumer purchasing behavior across the entire life cycle of a product. Similarly, in the course of our research, we performed a case study where complete seasonal data for fashion sandals was recorded and variables of attention, fitting and sales were used to establish the LCA model for fashion sandals. Results show that only moderate Bassfitting results were found for individual-level data; while, good to excellent results could be obtained for the accumulated data. Further, a moderate to good correlation was found between the sales and attention on one hand, and sale and fitting on the other. Regression 
models including Bass Model equations could be applied to predict the sales by either the attention or the fitting data.

Although positive outcomes were achieved, limitations exist and shall be considered in the further application of our protocols: we shall define the initial value for the aggregated Bass Model and that value shall be at least ten-thousand level. A value of less than 10000 attention or fitting records might result in unreliable predicted sales. Therefore, our Bass Model is suitable for a group or a large company which has a series of retailers; however, those with a single shop or simple data could not benefit from our models. In terms of further research, we will be focusing on the method to quantify the psychological variables in the consuming behavior, so as to evaluate the possibility of Bass modeling. Combining the physiological and psychological quantification, a complete consuming behavior for fast-fashion products could be established.

\section{CONCLUSIONS}

In this study, we first approved that the Bass modeling for consuming behavior is available; it also meant that other variables in the consuming process, even the psychological indicators would be modeled. Moreover, our RFID-based smart recording system is cheap and easy to install and it could be applied in the fast fashion apparel and footwear industry. Further, we discussed the correlations between the attention and sales, and fitting and sales; good to excellent regression reliability was found for these regression models, which implies that sales of fast-fashion products could be predicted based on the attention or the fitting data. Thereby, the theoretical domains of Bass model and traditional consuming behavior are extended.

Overall, we introduced the attention, fitting, and sales variables in the modeling of fast fashion sandals in China; and two Bass
Models including the use of individual and accumulated market data were established. Overall, variables of consumer behavior, such as attention and fitting, were found to be suitable for Bass Modeling; further they were found to be good indicators to predict sales. These efforts advanced the time required to predict the sales trend of fast fashion sandals and make the predictive protocols more reliable.

\section{Acknowledgements}

The authors thank all those who participated in the study, meanwhile we also thank the National Natural Science Foundation of China (31700813) and China Postdoctoral Science Foundation (2015M571896).

\section{REFERENCES}

1. Colucci, M., Scarpi, D., Generation Y: Evidences from the Fast-Fashion Market and Implications for Targeting, Paper presented at the $38^{\text {th }}$ COSPAR Scientific Assembly, Journal of Business Theory and Practice, 1, 1, 2013.

2. Calvo, E., Albéniz, V.M.D., Manage Sci, 2016, 62, 2, 436-455, https://doi. org/10.1287/mnsc.2014.2138.

3. Carlton, M., Insight, Sector study - FastFashion - Gap's expansion fuels Asia fashion war, Campaign Asia-Pacific, 2010.

4. Jin, T., Research on Gompertz curve model used for mobile user growth, Paper presented at the International Conference on Educational and Network Technology, 2010.

5. Bettman, J.R., Park, C.W., J Consum Res, 1980, 7, 3, 234-248, https://doi. org/10.1086/208812.

6. Bass, F.M., Manage Sci, 1969, 15, 5, 215-227, https://doi.org/10.1287/ mnsc.15.5.215. 
7. Cachon, G.P., Swinney, R., The Value of Fast Fashion: Quick Response, Enhanced Design, and Strategic Consumer Behavior: INFORMS., 2011, https://doi.org/10.1287/ mnsc.1100.1303.

8. Choi, E.K., Paradigm Innovation through the Strategic Collaboration between TORAY \& UNIQLO: Evolution of A New Fast Fashion Business Model, lir Working Paper, 2011.

9. Dahan, G.S., Peltekoglu, F.B., Journal of Global Fashion Marketing, 2011, 2, 1, 1-10, https://doi.org/10.1080/20932685.2011.1 0593077.

10. Guinée, J.B., Haes, H.A.U.D., Huppes, G., J Clean Prod, 1993, 1, 2, 81-91, https://doi. org/10.1016/0959-6526(93)90046-E.

11. Shin, S.J., Suh, S.H., Stroud, I., Yoon, S.C., J Intell Manuf, 2017, 28, 6, 1-19.

12. Thore, S.A., The Life Cycles of Sales and Profits: Dealing with the Uncertainties of the Commercialization Process: Springer US, 2002, https://doi.org/10.1007/978-14615-1001-7_5.

13. Groen, E.A., Heijungs, R., Bokkers, E.A.M., Boer, I.J.M.D., Schenck, R., Huizen, D., Sensitivity analysis in life cycle assessment, Paper presented at the Proceedings of the 9th International Conference on Life Cycle Assessment in the Agri-Food Sector (LCA Food 2014), San Francisco, California, USA, 8-10 October, 2014.

14. Peters, G.P., Int J Life Cycle Assess, 2017, 12, 6, 373-380, https://doi.org/10.1007/ s11367-006-0254-8.

15. Tummala, R.L., Koenig, B.E., Models for life cycle assessment of manufactured products, Paper presented at the IEEE International Symposium on Electronics and the Environment, 1994.

16. Mattila, T., Lehtoranta, S., Sokka, L., Melanen, M., Nissinen, A., J Ind Ecol, 2012,
16, 1, 51-60, https://doi.org/10.1111/ j.1530-9290.2011.00443.x.

17. Holcombe, D.G., Ellison, S.L.R., Accredit Qual Assur, 2001, 6, 8, 340-345, https:// doi.org/10.1007/s007690100361.

18. Peterkova, J., Nemcik, P., Vancura, V., Gottfried, J., Software support of managerial decision making based on system approach, Paper presented at the Carpathian Control Conference, 2012.

19. Gilshannon, S.T., Brown, D.R., Review of methods for forecasting the market penetration of new technologies, Office of Scientific \& Technical Information Technical Reports, 1996.

20. Yan, G.H., The Application of Gompertz Model of Product Life Cycle in the Prediction of the Selling Teaching Guidance Books, Journal of Shanxi Normal University, 2017.

21. Acquah, E.H.K., A Growth Model for Academic Program Life Cycle (APLC): A Theoretical and Empirical Analysis, Association for Institutional Research, 2010, 27.

22. Sokele, M., Analytical Method for Forecasting of Telecommunications Service Life-Cycle Quantitative Factors, Sveučilište u Zagrebu, 2019.

23. Bass, F.M., A New Product Growth for Model Consumer Durables, Manage Sci, 2004, 50, 12, https://doi.org/10.1287/ mnsc.1040.0264.

24. Guo, X., Int J Prod Econ, 2014, 158, C, 208-216, https://doi.org/10.1016/j. ijpe.2014.07.018.

25. Liu, F., Utilitarian and hedonic values of shopping experience in Chinese online $\mathrm{C} 2 \mathrm{C}$ market, Thesis, Hong Kong Polytechnic University, 2011.

26. Shahidi, M.N., The impact of product life cycle on strategic orientation of a entreprise, Review of Business Research, 2008. 
27. Howard, J.A., Sheth, J.N., The Theory of Buyer Behavior, J Am Stat Assoc, 1971.

28. Smith, J.R., Terry, D.J., Manstead, A.S., Louis, W.R., Kotterman, D., Wolfs, J., J Soc Psychol, 2008, 148, 3, 311-333, https://doi. org/10.3200/SOCP.148.3.311-334.
29. Evans, D.S., J Econ Perspect, 2009, 23, 3, 37-60, https://doi.org/10.1257/jep.23.3.37.

(C) 2019 by the author(s). Published by INCDTP-ICPI, Bucharest, RO. This is an open access article distributed under the terms and conditions of the Creative Commons Attribution license (http://creativecommons.org/licenses/ by/4.0/). 